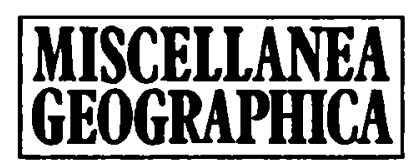

WARSZAWA 1994 Vol. 6

Elżbieta Puchnarewicz

\title{
FAMILY IN THE FARAFRA OASIS
}

The relations within an average family and its functions have not undergone noticeable transformation in recent years. As in the other rural communities in Egypt the patriarchal family structure has persisted, where the male chief holds a strong leading position, the younger is subservient to the elder and the customary norms of behaviour are different for the male and female.

At the head of the family there invariably stands the eldest man. As long as the senior of the family lives, his sons and daughters are materially dependent on him. His authority is further supported and extended by the patrilinear system of kinship and patrilocal family structure, where a bride after marriage moves to live in the husband's family house. The Farafran family is usually a multi-generation one. It consists of a household head and his wife (or wives), their unmarried sons and daughters, sometimes single brothers and sisters, as well as married sons with their wives and children. The extended family is regarded to be ideal because it is in harmony with the religious and, consequently, cultural principles. Islam has always been strongly in favour of marriage which was even commanded by the Koran (XXIV, 32), and the procreation of children is regarded as meritorious. For such it is generally held by the Farafrans, too. Besides, it gives a certain feeling of social stability and security, especially in the feared old age when it gives hope if not guarantee for expected assistance from its younger members. In addition, a large number of male children brings the family high esteem within the community.

It is very common, as elsewhere in Islamic countries, to take a relative in marriage. A preferable union within a family is between the first cousins, i.e. taking in marriage a paternal (more rarely maternal) uncle's daughter. The purpose of such a union is both economic and social and it is viewed as advantageous to the position of the whole extended family. The very farreaching relationship system stretched out by the high population growth makes that the family ties extend from the natural neighbourhood to the entire community of the oasis. There exists a complicated network of social links, including interrelated obligations, mutual support and assistance and 
influence in public sphere. In the tight bonds of small local community no one can be forgotten. The family and clan loyalties are apparent when new professions are to be created and new economic undertakings considered. The newcomer may at first meet with refusal to satisfy even his insignificant demands and this in spite of traditional hospitality of the Farafran people. The reason for such an attitude is usually the reluctance to encroach on a related person's field of activity or damage his interests.

Marriage as an institution obviously plays an extremely important social function; it enhances the familial and economic ties, as well as relations among neighbours. The integral part of the contract is the mahr, popularly taken to be a payment for a wife, but in essence and legally it is a payment to a wife, which supports her in case of undeserved divorce or death of a husband.

Girls marry usually between 14 and 17 years of age. Those who achieved certain educational level, enter into family bonds later in life. The choice of a partner is very often in the hands of the parents. Mostly it is a mother who takes it on her to choose a definite candidate and decide if he is a suitable one. Apparently it usually is so: the Farafrans know of only one divorce case and none confirmed an adultery instance. It would be looked upon as a breach of marriage ties affecting the entire village community interrelations. The occasional affairs between men and lady tourists are not regarded as concerning the community.

The Farafran people have some knowledge of family planning. Consultations and contraceptives are provided by the local hospital. Some men claim to have made use of condoms and one of the women mentioned in conversation contraceptive pills, spirals and pessaries. Insufficient education in this field and various traditional prejudices have led to nearly non-existence of family planning. Part of the problem certainly rests on the local public opinion and its condemnation or misjudgement of modern measures of birth control. In the community where everybody is acquainted with everybody else's affairs, there is a constant fear of the group disapproval.

Children are indispensable and precious part of the Islamic family. They secure the family's future and give assurance of material backing in an old age. Boys are valued more than girls and consequently are given more care. From early childhood they are prepared to assume the role of authority in the future family. In due course an eldest, married son will replace his father. Girls, on the other hand, from infancy are taught duties of wife and mother. They are taking care of younger brothers and sisters, preparing meals, baking bread, milking goats and sheep, bringing water, weaving baskets of palm leaves, shopping etc.

The Farafrans make it clear that they attach great attention to children's education. They are truly proud of the two existing schools. They, as well as the teachers, assure that all children in the oasis go to school. Education is considered to be a good investment; nevertheless, there is cer- 
tain fear for the young people that the modern education might lead to deterioration of the traditional norms of life. One of the fathers, fearing that his son might not return to the oasis and take his place in society in the future, accompanied him in the course of three years of education in town.

Schooling at the elementary level is co-educational. Its compulsory duration has been extended until the age of 15 . The joint education counteracts to some extent sex segregation which traditionally is incumbent on girls from the first menstruation. Since at Farafra all girls go to school until its completion and the classroom system obviously precludes segregation, it is delayed much beyond the traditional age of about 13 . A few girls even attend the newly opened secondary school, which evidently further extends contacts between the female and male youth groups.

The conversation with a teacher of English resulted in the information that pupils are eager to learn foreign languages. They regard them as one of the means to enhance chances of getting an attractive and interesting employment, not only from the pecuniary point of view.

People of the older generation look with suspicion upon the modern concepts coming from outside their familiar social environment even if they are brought by the school. But they are also conscious that the traditional home-informal education becomes difficult, especially because of the influence of television. A variety of programmes, many of them with bold advertisements and films, are alarming and threaten to damage good old rules and comportment based on strict religious morality and bring sinful and alien mores to the young people. In the meantime, however, the majority in a strict submission to Islam obeys Allah's commands and prohibitions believing that in due course in this as well as in the future life they will be recompensed (just as they would be punished for transgressions). Certainly, the system of beliefs in the rural, until recently largely isolated, community is much simplified. More subtle ideas common to speculative, intellectual orthodoxy, such as for example the notion of a free will, are unknown to them, just as to most of other Egyptians.

The traditional activities and comportment of men and women largely vary, which, as is firmly believed, is in accord with the prescripts of Islam. It can be observed in everyday life both at home and outside. Seclusion of women at Farafra is rigorously observed, just as the division of social and professional functions. Women stay at home and take care of children; men are active in public duties. Women pass all their life in private homesteads surrounded by walls. The extended family lives together usually under the same roof, although small, nuclear families occupy a separate room or part of a house with its own entrance from the common courtyard. Usually, a number of women is always present in one of the house compounds. They share their domestic duties and distribute them to individuals. Gradually, a hierarchical system of prestige is built in which the summit is occupied by 
the mother, a patriarch's wife. Women go outdoors to visit relatives or neighbours as well as to see a doctor. They also go to the garden to attend it, weed or bring home some vegetables, doing it usually early in the morning. They can leave the house only if assisted by the husband or other male from the family. They never take employment outside with the exception of those who are teachers or nurses, but they are escorted to and from the job by husbands or male relatives. Only one older woman proudly declared that she could walk alone. This was possible on account of her irreproachable reputation and prestige arriving with age. During breaks between lessons, female teachers are staying in special rooms assigned to ladies only. The sex segregation is also felt in medical practice: a male doctor is forbidden to enter a ward destined for female patients. For diagnosis and prescriptions he acts through the intermediary of a nurse who gives him accounts of the symptoms on the strength of which he makes his decision and prescribes the treatment. Obviously, in very grave cases there must be exceptions to this rule, but the presence of the husband and another women may be required.

At Farafra, just as in other Egyptian towns and localities, women do not pray in the mosque. At the time of Friday prayer, they leave houses, gather in groups and talk with each other. They dress on such occasions in colourful attires, evidently to stress the festive atmosphere and boast new clothes. Talking to women at Farafra, one does not perceive that they are unhappy with their situation. Seemingly, they became of old easily accustomed to their role in society and particular demeanour.

Men sojourn at home much less than women. Their occupations range from agriculture, teaching at schools, working in local administration, to keeping a shop or canteen, mechanical workshop or other small business or salaried job. In the free time, they usually sit at cafeterias or in front of their houses talking with other men. Their continuous staying at home without a valid reason, such as resting or taking meals, might be considered unnatural, unmanly or so. A natural place for a man is with other men rather than with his own family. Besides, this shows his involvement with community affairs.

There is an apparent strain or at least uneasiness concerning the traditional female place in society. On the one hand, there is an awareness of the need to include women too, not only men, in various activities or opportunities emerging in the changing village economy and letting them contribute to the family's income. On the other hand, the accepted custom, being a product of religious and cultural values, deemed positive if not salutary for the respectable society, constitutes a strong impediment. Men and women alike affirmed that the present model of women's demeanour ought to change. Especially young men commonly agree that the public sphere should be opened for women, although they themselves are not unanimously of that opinion. Men enquired for the reason for such an at- 
titude answered that they were afraid of the unfavourable public opinion, suspicion or misdemeanour and therefore did not want to alter their customary behaviour.

Stability of the social role, different in the case of men and women, for a long time accepted and largely unalterable, might have been aided by the fact that the life in the oasis is subjected to the laws typical of the small and isolated communities. Physically and geographically restricted inhabited space makes possible the total control of co-dwellers' comportment; this control is more effective still because of the strong patriarchal family structure.

\section{REFERENCES}

A m éli n e a u E. 1893, La géographie de l'Egypte à l'époque copte, Paris.

B a in et-B e y A. 1899, Dictionnaire Géographique de l'Egypte, Le Caire.

B e a d n el H.J.L. 1889, Farafra, Its topology and geology, Geological Survey of Egypt.

El-B e k ri , Abou-Obeid, 1965, Edittion et traduction par Mac Guckin de Slane, Paris.

Blis s F. 1983, Die Oasen Bahrija und Farafra, PAS Bonn.

B reas te d J.H. 1962, Ancient Records of Egypt. Historical Documents III.

C a illi a n d F. 1826, Voyage à Méroé au fleuve blanc au-delà de Fâzoql, Paris.

$\mathrm{D} \mathrm{u}$ q m a q I b n, Ed. Vollers, vol. IV-V, Cairo.

Encyclopaedia of Islam, Farafra, New Ed., vol. I; I Ed. vol. IL, Cairo.

Fakh ry A. 1973-74, The Oases of Egypt, I Siwa Oasis, II Bahria and Farafra Oasis, Cairo.

FAO, 1984, Agroecological Data. Africa, vol. 1, Rome.

Gauthier H. 1925, Dictionnaire des noms géographiques contenus dans les textet hierogliphiques, Le Caire.

Is t a k hri-a l, 1961, al-Masalik wal-mamalik, Ed. M. Jabir Abd al. Al al-Hani, Cairo

Maqriri-al, Khitat, 1864, Bulaq, vol. I.

Maspero J., Wi t $G$. 1919, "Materiaux pour servir à la géographie de l'Egypte", Mémoire de l'Institut d'Archéologie, vol. XXXVI, Le Caire.

M a s'u di - al, 1958, Oases, Ed. M. Muhiyad-Sin Abdal Khamed, al-Qahira vol. I-IV.

Qalqashandi-al Subh al-A'sha, Oases, reprint Ed. al-Amiriya, vol. III.

R a m ly I.M. 1964, The Use of Fissured Limestone in Locating Ground Water Resources and Its Application. The Farafra Oasis, New Valley "Area, Western Desert UAR", Transaction of the Arab Mining and Petroleum Association Bulletin, vol. XIX, pp.9-57, Cairo.

Ro e der G. 1927, Altählung und Märchen, Jena.

Salik Abu, 1959, The Churches and Monasteries of Egypt and some Neighbouring Countries, Oxford.

Set he K., Ägyptologische Zeitschrift, vol. LVI.

Suyuti-al Subh al-Mu ah ad a ra, 1967, Ed. M. Abu al-Fadl Ibrahim al-Halabi, alQahira.

Wagn er G. 1987, Les Oasis d'Egypte, IFAO, Le Caire.

Y a qu t N., 1869, Geographishes Wörterbuch, Ed. F. Wüstenfeld, Leipzig.

Y a k u be, 1937, Les pays, trad. Gaston Wiet, Le Caire. 